\title{
Digital Making in Educational Projects
}

Alejandra Bosco ${ }^{\star 1}$, Noemí Santiveri ${ }^{2}$ and Susanna Tesconi ${ }^{3}$

$\propto$ Digital Making as an Educational Project is an innovative educational experience that has been carried out with students of the Primary Education and Social Education degrees for three consecutive years. The experience introduces digital making as an activity in which students create an object using digital technology. In the process, they not only gain an insight into how the technology works, but also learn the content and competences of the curriculum. This innovative teaching practice was carried out as action research in order to improve traditional higher education practices. In this sense, the proposal puts the student at the centre of the process as the author and protagonist of their own learning process. The experience is based on their own interests: they decide what to make based on a given context. The students work in groups and look for what they need to learn to overcome a particular challenge, while the teacher supports the process as a facilitator, offering guidance and resources when necessary. The evaluation of the whole process is regulated via a group diary (a shared online document) and an individual diary (a blog) that the students produce. The final evaluation is not only of the printed product; the students also produce a video in the form of storytelling, in which they explain how the process evolved from the initial idea to the final impression of the object. They also reflect on what they have learned, how teamwork has worked and what possibilities they believe digital making offers in the primary and non-formal educational contexts in which they will work. All of the processes are compiled in the students' blogs, as well as in the teachers' field notebooks. The experience was executed in collaboration with the Digital Fabrication Centres of Barcelona. The results were organised to highlight the strengths and weaknesses of using technologies to improve higher education offering an approach in which students are at the centre of the whole process. Strengths: strong student motivation, promotion of self-directed and collaborative learning and learning by doing, and familiarisation with

$1{ }^{\star}$ Corresponding Author. Departament of Applied Pedagogy, Autonomous University of Barcelona, Spain; alejandra.bosco@uab.cat.

2 Departament of Applied Pedagogy, Autonomous University of Barcelona, Spain.

3 Faculty of Computer Science, Multimedia and Telecommunications, Open University of Catalonia, Spain. 
a transforming integration of technology as protagonists. Weaknesses: hesitance and resistance to facing the challenge, management of scarce time, large time investment by the teachers, and the difficulty of achieving in-depth reflection on how digital fabrication could be introduced in educational contexts such as primary school and non-formal contexts.

Keywords: educational innovation, ICT, making, autonomous learning, collaborative learning 


\section{Digitalno ustvarjanje v izobraževalnih projektih}

Alejandra Bosco, Noemí Santiveri in Susanna Tesconi

$\propto$ Digitalno ustvarjanje kot izobraževalni projekt je inovativna izobraževalna izkušnja, ki jo že tri leta zapored izvajamo s študenti smeri osnovnega in socialnega izobraževanja. Izkušnja uvaja digitalno ustvarjanje kot aktivnost, v okviru katere študentje ustvarijo predmet $\mathrm{s}$ pomočjo digitalne tehnologije. $V$ tem procesu ne pridobijo le vpogleda $\mathrm{v}$ to, kako tehnologija deluje, ampak usvajajo tudi kurikularne vsebine in kompetence. $\mathrm{Z}$ namenom izboljševanja tradicionalnih visokošolskih izobraževalnih praks je bila ta poučevalna praksa izvedena kot akcijsko raziskovanje. $\mathrm{V}$ tem smislu predlog postavi študenta $\mathrm{v}$ središče procesa kot avtorja in nosilca lastnega učnega procesa. Izkušnja temelji na njihovem lastnem interesu: sami se odločijo, kaj bodo naredili glede na dani kontekst. Študentje delajo v skupinah in ugotavljajo, kaj se morajo naučiti, da lahko presežejo določen izziv, medtem ko učitelj postopek podpira kot spodbujevalec ter po potrebi nudi usmeritve in vire. Evalvacijo celotnega procesa usmerjata skupinski dnevnik (skupni spletni dokument) in individualni (blog) dnevnik, ki ju ustvarjajo študentje. $\mathrm{V}$ okviru končne evalvacije ni ocenjen le natisnjen produkt, ampak tudi videoposnetek v obliki pripovedovanja zgodbe, $\mathrm{v}$ kateri študentje pojasnijo, kako se je proces razvijal od začetne ideje do končnega vtisa predmeta. Študentje prav tako reflektirajo o tem, česa so se naučili, kako je potekalo skupinsko delo in o možnostih, za katere verjamejo, da jih ponuja digitalno ustvarjanje v osnovnošolskem in neformalnem izobraževalnem kontekstu, v katerem bodo delovali. Vsi procesi so zbrani $\mathrm{v}$ študentskih blogih pa tudi $\mathrm{v}$ učiteljevih terenskih zapiskih. Izkušnja je bila izpeljana v sodelovanju z Digital Fabrication Centres iz Barcelone. Rezultati so bili organizirani tako, da so poudarili prednosti in slabosti uporabe tehnologij za izboljšanje visokošolskega izobraževanja $\mathrm{z}$ omogočanjem pristopa, $\mathrm{v}$ katerem so študentje v središču celotnega procesa. Prednosti: visoka motivacija študentov, spodbujanje samousmerjajočega, skupinskega učenja in učenja $\mathrm{z}$ delovanjem ter seznanjanje s transformativno integracijo tehnologije kot protagonistke. Slabosti: omahovanje in odpor do spoprijemanja z izzivi, upravljanje z omejenim časom, velik časovni vložek učiteljev in težave pri doseganju poglobljenega premisleka o tem, kako 
bi lahko digitalno izdelovanje vpeljali v izobraževalne kontekste, kot sta osnovnošolski in neformalni.

Ključne besede: inovativnost v izobraževanju, IKT, ustvarjanje, avtonomno učenje, skupinsko učenje 


\section{Justification of innovation: Digital making as an educational project}

The integration of technology into educational contexts in Catalonia and the rest of Spain has been dictated more by the purchase and introduction of artefacts than by the development of educational innovations aimed at improving education. This has also occurred in the international context. Many studies show that, despite the increase in technological resources in schools, the pedagogical practices of teaching staff continue to be anchored in so-called traditional education. There are few experiences and projects that lead to an improvement understood as the establishment of a pedagogy linked to new ways of creating knowledge and offering students and the group greater protagonism when learning (Area, 2008, 2011; Balanskat, Blamire, \& Kefala, 2006; Bosco Paniagua, Larraín Pfingsthorn, \& Sancho Gil, 20o8; Bosco, Sánchez-Valero, \& Sancho, 2016; Condie \& Munro, 2007; Cuban, 1993; Meneses, Fàbregues, Jacovkis, \& Rodríguez-Gómez, 2014; Sancho, 2006; Sancho \& Alonso, 2012; Sigalés, Mominó, \& Meneses, 2007; Sigalés, Mominó, Meneses, \& Badía, 2008).

Nevertheless, some of the technological resources that could be considered tendencies today, such as robotics and programming, increased reality, open educational resources or the social web, are perfectly compatible with supporting this type of educational innovation. This is also true of digital fabrication or making, on which the innovative educational experience presented in this paper is based.

Although making and the DIY philosophy on which it is sustained are very complex social phenomena that affect different spheres of social and economic life (Tesconi, 2018), the ideas and practices that characterise them are very significant for those interested in the creative integration of technology in educational contexts, linked to active pedagogy and promoting self-directed learning based on investigation.

More specifically, the maker movement (making or maker culture) refers to a growing number of people who mainly share an interest in making things themselves (DIY), in the use of digital tools to create objects, and in sharing and collaborating online around these questions. The maker culture emphasises learning through working in a social atmosphere, on the web and motivated by self-production (Dougherty, 2013; Halverson \& Sheridan, 2014; Martin, 2015; Tesconi \& Arias, 2015, Tesconi, 2015, 2017, 2018).

The basic infrastructures that enable the development of the maker culture are fablabs, makerspaces and virtual communities, together with a series of technological tools including both software (e.g., $3 \mathrm{D}$ design programmes) and 
hardware (e.g., 3D and laser printers), which enable the design and finally the physical creation of the objects, respectively. Although digital fabrication refers more to the tools used for creating objects, and making more to the interpersonal dynamics that allow the construction of joint knowledge, both are two sides of the same coin.

In recent years, the spread of rapid prototyping tools (a technique used to manufacture articles via $3 \mathrm{D}$ printers) and digital manufacturing laboratories (Fab Labs: Fabrication Laboratory), which facilitate the design and construction of objects, has given rise to a movement to democratise technology. It is a movement that is also making its presence felt in formal and non-formal education through various programmes, some linked to the integration of robotics and programming, whose presence has been gradually increasing in education since at least 2012 (Acción Cultural Española -AC/E-, 2015; Orange Foundation, 2016; Informe Intef, 2018). In particular, in the last five years in the USA, educators have taken an interest due to the high failure rate in the spheres of science and technology. More specifically, in 2012, the Obama administration launched a programme to implant these spaces (fablabs or makerspaces) over the subsequent four years in more than one thousand schools, providing them with suitable tools for digital making (Orange Foundation, 2016). Initiatives based on the maker philosophy have also begun to be implemented in the Spanish State, in the spheres of both formal and non-formal education, leading to programmes aimed at diverse groups of children and young people, developed by public and private institutions. Some examples of these initiatives in the Spanish State are: 1) The fabLab of the Liceu Politécnic of Rubí (Province of Barcelona) of the FabLab@School initiative promoted by the Transformative Learning Technologies Lab of the University of Stanford, which proposes the creation of a FabLab in each school as a learning resource. The Liceu Politecnic offers digital fabrication and maker-centred learning environments for middle and high school students. Since 2014, the project has involved approximately 80 students and 4 teachers. 2) The Young Aspies Makers, a result of public-private collaboration aimed at young people with Asperger's, who develop $3 \mathrm{D}$ printing projects to improve the autonomy of disabled persons (Barcelona). This project, started in 2015, has had three editions of the two-week workshops, involving 30 students aged between 15 and 18. 3) The digital making workshops for young people of Xtreme, a non-profit association in Almendralejo (Extremadura), where an after-school programme aimed at raising the awareness of digital fabrication technology has been implemented. 4) $A u L A B$, in Asturias, the result of collaboration between the public art centre LABoral Centro de Arte and the local education ministry. It is the first implementation in the Spanish State 
of digital fabrication and making in formal educational contexts. The project took place from 2012 to 2016 and involved 72 public schools (from primary to secondary), 45 teachers and 285 students over a nine-month period (Orange Foundation, 2016). In addition, the Digital Fabrication Cultural Centres in the city of Barcelona, with which we have collaborated in this experience, have a pedagogical programme aimed at bringing digital manufacturing and making to schools.

More specifically, in the words of Martin (2015, p. 31), we can say that making refers to "A class of activity focused on designing, building, modifying, and/or repurposing material objects, for playful or useful ends, oriented toward making a 'product' of some sort that can be used, interacted with, or demonstrated. Making often involves traditional craft and hobby techniques (e.g. sewing, woodworking, etc.) and it often involves the use of digital technologies, either for manufacture (e.g. laser cutters, $\mathrm{CNC}$ machines, $3 \mathrm{D}$ printers) or within the design..."

Dougherty (2013) synthesises make culture as: 1) A human activity originating from an individual interest in wanting to create an object, environment or system that is important for the person who creates it and/or for their environment. The driving force behind it is a ludic attitude, while the maker is a person who plays with technology to learn about it. 2) An activity that promotes a positive attitude towards the acquisition of knowledge. The motivation generated by personal interest and free choice encourages the learning of the skills and know-how needed to continue creating. The apprentice is responsible for and chooses his/her own learning path. 3) An activity that values mistakemaking as a fundamental resource, capable of activating new learning processes; and 4) A highly collaborative activity based on sharing ideas and projects, as well as on supporting others in their creative processes.

All of these characteristics mean that making is an ideal practice for those who want to promote the educational improvement mentioned above; in other words, starting from the DIY philosophy, promoting authorship, digital competence based on production rather than the mere consumption of information, creativity, self-directed learning, and working from the genuine interests and investigations of the students themselves (Buckingham, 2003; Blikstein, 2013; Hsu, Baldwin, \& Ching, 2017; Peppler, Halverson, \& Kafai, 2016). On the other hand, these are actions sustained by what we know about how to learn better if we want to promote competent subjects for $21^{\text {st }}$ century society (Bosco et al., 2008; Hernández, 2006; Stoll, Fink, \& Earl, 2004). With this in mind, making can be considered an educational practice based on investigation (Vossoughi \& Bevan, 2015), compatible with working through projects and collaboration. 
This philosophy is what gives sense to the experience of teaching innovation presented in this article, for which we provide the context and the main characteristics in the following sections.

\section{Contextualisation of the experience}

The experience of innovation, Digital Making as an Educational Project, was undertaken in the subject Educational Communication and Interaction II, which is a basic training subject of the first year for teacher training degrees in Infant and Primary Education, Social Education and Pedagogy of the Faculty of Education Sciences at the Autonomous University of Barcelona. The majority of students enrolled in this subject are between 18 and 20 years old. The subject has six credits and is divided into two clearly differentiated thematic blocks: Technologies of Learning and Knowledge, and Groups and Emotions. One of its main objectives is to develop skills for the use of information and communication technologies at the service of learning and teaching, and for working in collaboration. To achieve these objectives during three consecutive academic years, in two of the eight groups in the subject we have developed a methodology inspired by the philosophy of the DIY movement, in work projects introducing $3 \mathrm{D}$ modelling and digital fabrication as an example of the creative integration of technology in educational contexts, based on the creation of objects. The proposal has been made possible thanks to collaboration with the Consortium of Education of Barcelona ${ }^{4}$ by means of joint work with the Ateneu de Fabricació Digital de Ciutat Meridiana (similar to a FabLab, but of a public nature), one of three centres in the city. Knowledge related to making and digital fabrication (process, software, approach) was new to the students, who generally deal with overall office automation and social media software.

The proposal was executed over three consecutive years - the 2015/16, 2016/17 and 2017/18 academic years - resulting in an extensive exhibition in $2017 / 18$ to coincide with the $25^{\text {th }}$ anniversary of the Faculty of Education Sciences of the Autonomous University of Barcelona, at which all of the objects created were on display, along with the learning experiences resulting from graphic resources (posters) and audiovisual media (videos). The next section details the more specific characteristics of the experience. ${ }^{6}$

4 For more about the Consortium, see: https://www.edubcn.cat/ca/el_consorci.

5 Barcelona currently has three centres located in different parts of the city: the districts of Les Corts, Barceloneta and Ciutat Meridiana.

6 The video at https://www.youtube.com/watch? $\mathrm{v}=\mathrm{tshye} 8 \mathrm{BoWoI} \& \mathrm{t}=4 \mathrm{~s}$ illustrates the experience as part of the exhibition. 


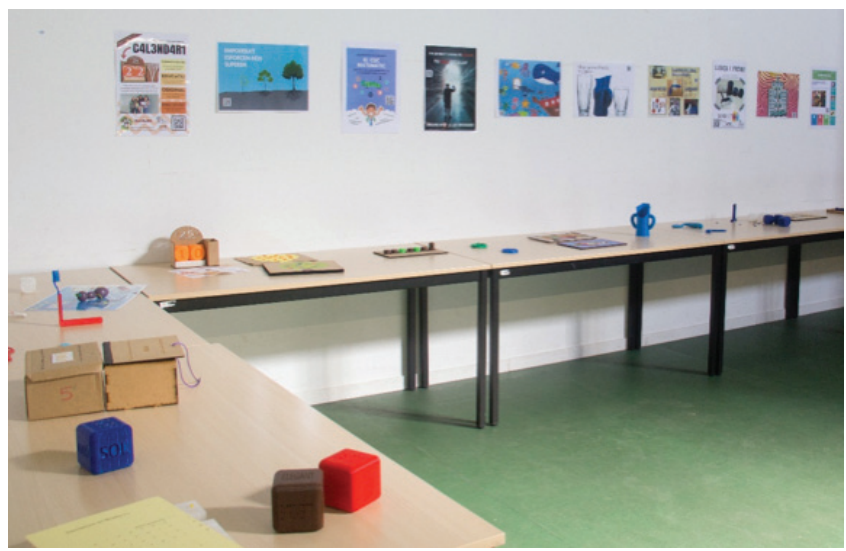

Figure 1. Image of the exhibition of projects on the $25^{\text {th }}$ anniversary of the Faculty of Education Sciences.

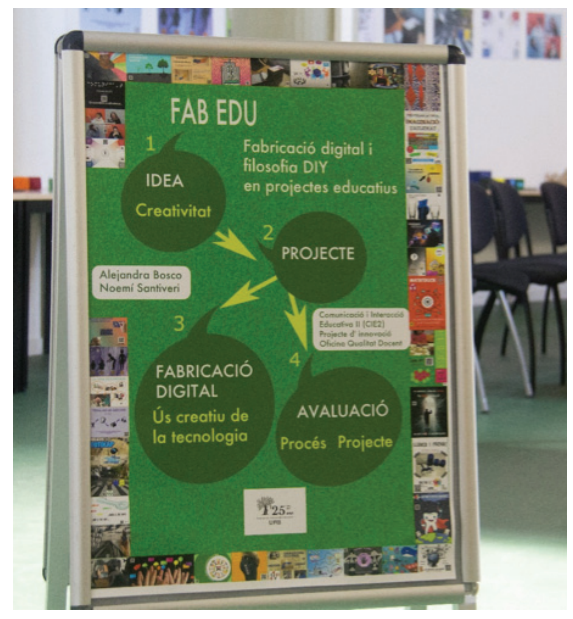

Figure 2. Image of the poster for the exhibition.

\section{The experience itself: Main features}

The subject with six credits is organised around several classroom-based sessions with a total of 18 hours, involving content related to the integration of ICT for learning and collaboration work. The students must also complete another 45 hours of self-directed work outside the class. The majority of the classroom-based sessions are focused on the development of practical activities around the projects defined by the students for the production of an object with the support of the teaching staff, who act as guides. Also included are 
activities supervised by the teaching staff, such as tutorials, which are not only classroom-based but also virtual (online).

The development of the experience is organised around three stages:

Introductory Stage. This stage consists of an introduction to digital manufacturing or making and its significance in current educational contexts, an initial approach to $3 \mathrm{D}$ design software, and a visit to the Ateneu de Fabricació to discover the machines and attend a $3 \mathrm{D}$ design workshop. This visit ends with the printing of some of the objects designed by the students. In these sessions, the work is mostly individual and deals with producing a very simple object, which enables the students to discover the field of work and to find out about the software and machines.

Design Stage. This corresponds to the design process of the object itself. It is a stage that is always undertaken in work groups, starting from the definition of the object the students want to create (work project) under the guidance of the teaching staff. Generally speaking, the object is framed within a more global educational project that gives it meaning; for example, if the idea is to create a game to promote mathematical thought, the underlying project could be to offer a more entertaining way to work with mathematics. This design stage is the most extensive stage, and is usually divided into three moments: a) definition of the object to create (and of the project in which it is framed), b) design of the object as a physical model (using paper, card or the most appropriate material) with the real measurements that it will have, and c) digital design of the object with the Tinkercad programme or similar.
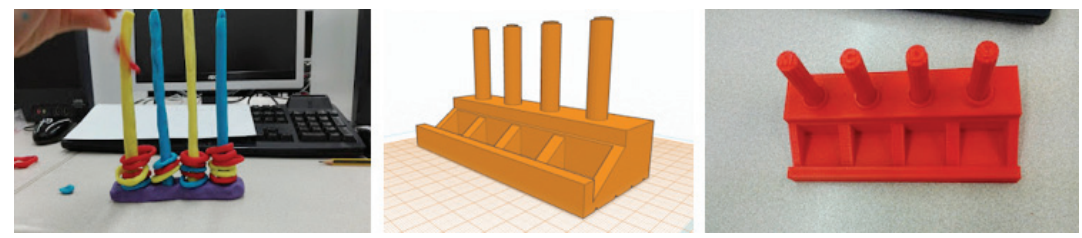

Figure 3. Image illustrating the production process from the model, through the digital design, to the final impressed object.
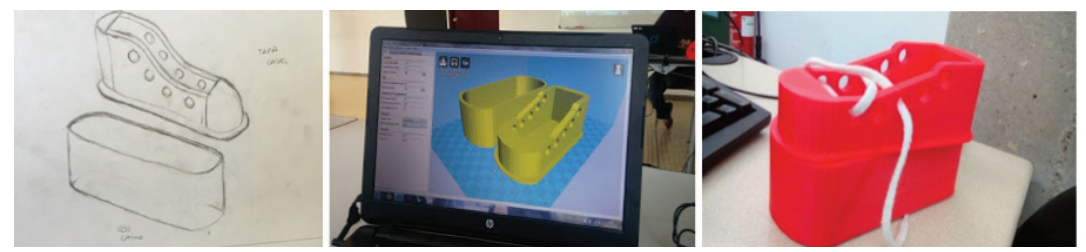

Figure 4. Image illustrating the production process from the model, through the digital design, to the final impressed object. 
Production Stage. This stage represents the moment of impression, either cut or engraved depending on the machine used, in the Ateneu de Fabricació Digital, preceded by a study of the preliminary digital designs in order to make the final modifications to adapt each proposal to: 1) the possibilities of the hardware (the type of machine that should be used); 2) the impression time; and 3) the material available (wood, card, PLA - polylactic acid, biodegradable, derived from maize - or another). This stage takes place entirely in the Ateneu de Fabricació Digital, thanks to the collaboration established between the Consortium of Education of Barcelona and the university.
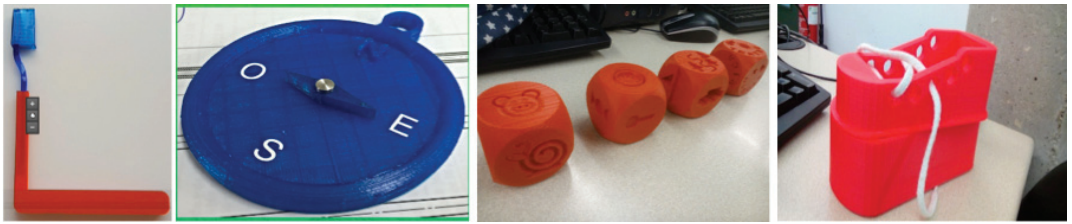

Figure 5. Images showing some of the impressed objects.

Final Evaluation and Diffusion Stage. This stage has two parts. 1) Development and presentation of the visual narrative that documents the whole process, from the original idea to the manufacturing fact. This narrative becomes one of the main elements of the final evaluation and takes the form of "digital storytelling" (DST) that documents and reflects on the learning process. DST or digital storytelling is a means used to tell and reflect on stories in depth using digital multimedia tools. Applied to the field of evaluation, it offers detailed information about the learning process (qualitative evaluation) as well as being a social communication tool for diffusion (Couldry, 2008). It is assumed that the student has been compiling all of the audiovisual material (videos, photographs, audio, screenshots, etc.) so as to be prepared to tell the story immediately after the process of impression of the objects. This narrative normally consists of a video of no more than three minutes and a poster. The idea is for the student to reflect on the whole process followed in terms of what they have learnt, and on the possibilities that the proposal might offer other educational contexts, especially the students' future working environments. This presentation is done in the class group. 2) Exhibition of the objects, posters and videos (in QR format from the poster) in the context of the group on completing the subject by each seminar participant (each group of the subject is divided into three seminars, each of approximately $25 \mathrm{stu}$ dents who undertake the course consecutively from September to June). For the $25^{\text {th }}$ anniversary of the Faculty of Education Sciences (UAB), the exhibition was opened to the whole faculty, teaching staff and students for a period of 15 days. 

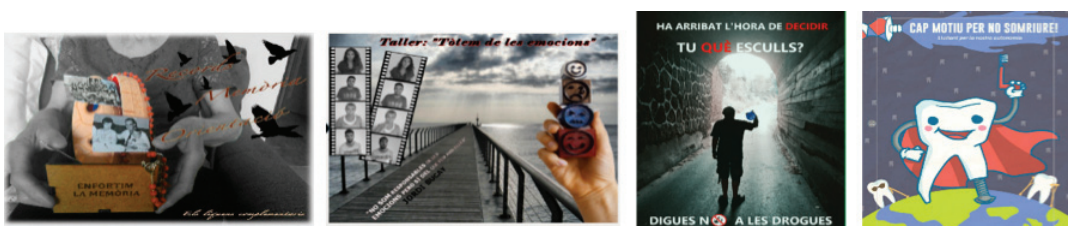

Figure 6. Posters showing the objects produced.

\section{Methodology approach}

This experience of teaching innovation had the clear aim of introducing an improvement, so it was proposed as action research. As such, it represents a small-scale intervention in the functioning of the real world and an analysis of its effects. Its aim is transformation; later, when the time is right, it establishes the basis for reaching theoretical conclusions, thus generating theory from practice (Elliot, 1991). More specifically, it is a design of research-action oriented towards decision-making from a practical point of view, as the aim is to improve and transform the educational proposals.

Although this article presents the results obtained from its implementation in the teacher training degree in Primary Education, the innovation was undertaken in two groups of the subject (Educational Communication and Interaction $I I$ ), with students from both Primary Education (178 students) and Social Education (249) throughout three consecutive courses (from 2015 to 2018) involving two teachers (full-time staff) and one assistant with experience in making, who worked in collaboration.

The data were compiled through observation of the teaching staff and through their field notes, as well as through the diaries of the students, who documented the entire process in both group and individual diaries. The former documented the work done from session to session, while the latter were used to document the learning process: what the students' needed to know, where they felt they were weaker, which resources they needed to look for, all in order to make decisions that would lead to an improvement in their individual performance and, consequently, the performance of the group. Another source of data was the self-evaluation that the students completed at the end of the subject. In addition, all of the graphic and audiovisual material produced (videos and posters) also constituted a source of data (Dussel \& Gutiérrez, 2006; Van Maanen, 2011). Content analysis (Flick, 2004) was undertaken, looking for issues that helped achieve the aims of the innovative experience, as well as other issues that were obstacles. Some of the categories that emerged coincide with those that promote or hinder educational innovation and the innovative use of 
technology, such as the kind of curricula (pre-established or not), the degree of student autonomy, the learning approach or the organisation of time and space (Area, 2008, 2011; Sancho \& Alonso, 2012).

\section{Results and discussion}

The results are organised around the strengths and weaknesses of the experience. This enables us to visualise the issues that can be relied on to continue the project or implement another similar experience, while highlighting the aspects that require redefinition.

\section{Strengths}

We find the strengths in the motivation and involvement of the students throughout the process, and in the effects that the promotion of self-directed learning - in collaboration and through doing and research - had on the student body. Not only with regard to what was learnt, but also the way in which it was learnt. Finally, the value given to the experience as an example of the meaningful integration of technology in the educational context.

\section{Motivation, initiative and implication}

One of the main results of this experience was the high degree of motivation that the student body experienced, resulting in it undertaking all of the tasks necessary to successfully complete the process of producing the object. The main source of this motivation was the fact that the students themselves were allowed to decide what to do. They therefore worked based on their own interests, for which they were prepared to do whatever was necessary, that is, to produce an object that motivates them. This generates a different level of commitment than merely following a remote syllabus. The challenge also activates all of their potential. Both of these characteristics have been shown to be very positive in producing authentic learning (Bosco et al., 2008; Hernández, 2004, 2006; Stoll et al., 2004). Recent studies based on neuroscience also state the importance of motivation to learn, and how this is strengthened by the focuses of alternative teaching, among other factors (Calatayud Salom, 2018; Navarro, 2018). Moreover, other experiences based on DIY philosophy coincide in the positive evaluation of the students regarding working from their own interests, with digital devices, in different spaces and autonomously (Domingo, Onsés, \& Sancho, 2018; Miño, Domingo, \& Sancho, 2018). Some students expressed their motivation and interest in the following way: 
"Once we had finished the subject, I discovered that through technology it is also possible to learn in a very useful way, boosting the autonomy and creativity of the children so they don't always have to do what the teachers tell them, following established guidelines." (student self-evaluation)

"Most important, however, is that at all times we were motivated to do the project and we ably dealt with difficulties that arose throughout it ..." (student diary)

"The motivation and commitment of the students is very high in this project." (field notes - teacher)

These results contrast with making experiences undertaken with teachers, who felt very uncomfortable in this type of open syllabus in which they learn what they need as they go according to the project to be developed (Tesconi, 2017, 2018).

\section{Working based on projects: Self-directed learning and collaboration}

Working collaboratively but in a self-directed process based on the development of a project was another strength of the experience. This had multiple benefits, as the students say they learned: 1) to work in a team, 2) to share interests with their colleagues, 3) to place the common interest above the individual, 4) to share knowledge more easily and support the qualities of each member, 5) to open up to the group, to listen to the proposals of colleagues and respect their opinions and ways of working, and 6) to organise themselves. All of these aspects are particularly strengthened in the proposals based on projects that prime the social nature of the learning (Hernández 2004, 2006). Moreover, these questions have already been documented in the literature about collaborative learning and project-based work (Hernández, 2004, 2006; Lobato, Apodaca, Barandiarán, \& San José, 2010; Romero \& Guitert, 2012; Stoll et al., 2004). They are also central to other experiences based on DIY in which students value positively self-directed learning in collaboration (Domingo et al., 2018; Miño et al., 2019; Tesconi, 2018). Finally, collective work is also highly valued from the perspective of neuroscience and neurodidactics as an element that favours learning (Navarro, 2018). This is how the students referred to collaborative work:

"I think the fact of working in a group is a very positive aspect. The fact that there are diverse points of view and sharing knowledge always enriches you as a person. Moreover, when a member of the group had a difficulty everyone responded in order to solve it." (student self-evaluation) 
“... I'm learning to work with people I didn't know, all of us getting involved in a totally unknown world for us, since we had never worked with programmes like this. Therefore, I've been able to learn to make these programmes work, to bring cohesion to a group making the most of the strong points of each one." (student diary)

\section{Offering an experience of the meaningful integration of technology}

The experience developed enables the students to experience first-hand a project that breaks with traditional pedagogy by integrating technology. In other words, the students worked on the content of the subject in an experimental way, which, it is assumed, will help them to transfer it to their future working contexts. This is how the students express it:

"When we finished the subject, I learnt that you can also learn in a very useful way through technology, boosting the autonomy and creativity of the children ..." (student self-evaluation)

"The experience in the first person that may involve, from the point of view of learning, a significant integration of technology in educational contexts." (field notes - teacher reflections)

\section{Weaknesses to address}

We see the main weaknesses in the caution and resistance shown when designing projects and thinking of objects to create, and in the short duration of the experience. Another weakness is the difficulty that the students had documenting their learning process and reflecting on it personally and deeply.

\section{Caution, resistance and frustration}

Despite having a motivating effect, the fact that the students themselves decided which project they were going to develop also caused a certain blockage and concern. In reality, having to decide places the students in a new situation, which is not free of tensions. Consequently, they initially tried to adopt simpler ideas, something that Blikstein (2013) calls the "keychain syndrome"?

These tensions have also been experienced in other DIY activities, and result from placing the student in an active role. Making their own decisions

7 "The keychain syndrome... revealed two of the crucial elements of learning environments based on digital fabrication. First, the equipment is capable of easily generating aesthetically attractive objects and products. Second, this generates an incentive system in which there is a disproportionate payoff in staying a 'local minimum' where the projects are very simple but at the same time highly admired by external observers. Settling for simple projects is a temptation that educators have to avoid at all cost." (Blikstein, 2013, p. 10) 
produces a certain insecurity in students (Miño et al., 2019; Tesconi, 2017, 2018): "Choosing the object we would make was not as easy as we had initially thought ..." (student diary)

Another moment of insecurity and frustration occurred in the production stage, when the students had to modify the prototypes (the first version of the objects designed) to adjust them to the printing time or the materials available, and when, occasionally, the product did not turn out as expected. Some students experienced an error as failure rather than as a normal step in the process:

"Then, the technicians told us that we had to separate the whole structure, to print it with laser, and add some fittings to each part so that it could be properly joined together. Hearing this the first time was quite stressful for us, since we had spent many hours of work making the structure and now it couldn't be printed. But with patience and effort, gradually between everyone we tried separating the whole structure and placing the fittings." (student diary)

"Today, the teacher brought us the printed object, since on the last day we ran out of time in the Ateneu. Personally, I really enjoyed seeing the object physically, but there had been a problem with the measurements and it came out smaller than we had expected and we had to reprint the images of the puzzle. In any case, we were very happy to have arrived at the final point of this project." (student diary)

\section{Management of scarce time and different spaces}

Organising the times in the university and the production centre had its difficulties, given that we had to connect two institutional spaces with different logics of functioning. However, the main problem was the scarce and fragmented working time that we had for the project. This problem is extensively documented in the bibliography, which refers to school grammar (Tyack \& Tobin, 1994) as the main drawback to developing innovative educational projects of whatever type (Bosco, 2005, 2013; Sancho \& Alonso, 2012). It does not calculate the time required to learn in accordance with the tasks to be undertaken, but based on what the institution offers us. This question is as difficult to solve as how to organise the time in the university:

"Finally, as a summary of the whole process, I think that all of the members of the group have worked really well... the only inconvenience I have had is time. I think that a project like this one, in order to be efficient and for it to be a more useful project in our everyday life, requires 
more time, so that it can be executed better, with more attention paid to small details." (group diary).

"What I think has lacked in the learning of the subject is the time factor; due to the lack of time, we have not been able to study the questions in depth." (student self-evaluation).

\section{Investment of time by the teachers and other tensions}

As with the students, the change of perspective also produced a certain tension among the teachers, who became the guides for the project decided upon by the students. On the one hand, this guide requires instructions tailormade for each group, which involves a major time investment, seeking out the appropriate resources and materials that can help the students to take the proposal forward. On the other hand, it involves entering a new world, that of digital fabrication, in terms of knowing the suitable programmes and the possibilities of the machines. All of this requires a major time investment, which is only reduced by the experience accumulated year after year:

"I have already explored three different programmes to meet the needs of the different projects, I don't know if the project will be sustainable in the long term." (field notes - teacher)

The new role requires overseeing a process in which not all of the answers are known. Sometimes it involves inquiring jointly with the student. In this particular situation, the first year of the experience was difficult to deal with, but the experience of the three years has allowed us to create strategies to guide the process in order to achieve success.

\section{Difficulties in documenting the experience}

Teaching processes that promote metacognitive processes are very positive in terms of learning (Calatayud Salom, 2018; Hernández, 2006; Bosco et al., 2008; Navarro, 2018; Stoll et al., 2004). An important part of this experience is therefore dedicated to documenting the processes undertaken through diaries and graphic documents such as storytelling. However, it is not easy for the students to document the process in depth. Many of them focused more on the technical and factual knowledge they acquired, such as the computer programmes they had learnt to use or the occasional work with a tool, rather than on the problems they had in their approach, or how they had been affected when their ideas were accepted or rejected:

“...We have finished today's session with all of the preparations for having the object and the exhibition ready for the next class. We have made 
the video explaining the whole procedure of the project with Moviemaker, and we have also made the poster..." (individual student diary).

It is more towards the end of the whole process that the participants are capable of undertaking deeper reflection on what has happened, what they have learnt and how. This is due to the small amount of experience they have in participating in more thoughtful teaching and learning processes. Once they have this experience, they are capable of evaluating it in another way:

"Nevertheless, I liked it very much that we didn't just do the physical project and that was that; we also had to write a diary of creation, make a video explaining the process, make a poster... It has been quite a complete subject." (student self-evaluation)

"It has also been very useful doing this personal blog in order to explain everything we have been learning. I have liked this format of evaluation very much." (student self-evaluation)

This difficulty is also evident in similar experiences with teachers, who were not able to recognise the usefulness of the documentation, viewing it more as a tool of control (Tesconi, 2017, 2018).

\section{Little reflection on how making could be introduced into educational contexts}

The experience is undertaken in a short and fragmented time, with the addition of the necessary coordination with the production centre. Nearly all of the efforts are concentrated in the production of the object, and only at the end is there space for pedagogical reflection, as future teachers, about the possibilities of integrating making into educational contexts. Such integration would be aimed at developing projects that, through making and production, would enhance the development of competences and enable the future teachers to approach different educational and curricular objectives. This reflection rarely occurs, and usually not until the end, without the possibility of going deeper into the experience or testing how a project of this nature could be designed. Nevertheless, some students, albeit very generally, questioned the specifics:

"Personally, I think that all of these new concepts that I have acquired have enabled me to know much more about the digital world. Today, technology is a very important factor in our lives, and so it will be in education, too. This is why I consider that all of the knowledge I have gained after completing the subject will be good for me as a future teacher." (student self-evaluation) 
"Throughout this process of the creation of the project, I have asked myself diverse questions, most of which have been in relation to the functioning of the Tinkercad programme. But I have also asked myself how a subject related to the creation of digital making could be applied to primary school classrooms." (student self-evaluation)

\section{Conclusions}

The experience developed shows the possibilities that making and digital fabrication can offer to innovation, and exemplifies the meaningful integration of technology in educational contexts in terms of learning. The experience is strong due to the motivation produced in the students by working on a project based on their own interest. This is also true of the challenge represented by the development of the project, although it produces tensions, too. The setting of the group in which the project develops helps achieve the objectives and increases the possibility of success, while also enabling students to learn how to work together. As with innovations, however, there are barriers related to the fragmented organisation of time that make the realisation of the project difficult, as it requires more time of both students and teachers, given that the roles to be carried out are distinct. A much more reflexive teaching and learning subject is sought, in an undertaking that must adapt to each situation, and where there are no written rules about exactly how and where it is going. The sustainability of the proposal lies in being able to solve these difficulties in order to multiply the benefits, making it extensive to other groups of the subject and in other contexts. In summary, the results contribute to acquiring the ability to manage this kind of innovative project and to use information and communication technologies in a university where content-centred and teacher-centred teaching approaches are predominant.

\section{Acknowledgement}

We appreciate the recognition of this innovative educational experience as a good practice by the Office of Teaching Quality of the Autonomous University of Barcelona. 


\section{References}

Acción Cultural Española -AC/E- (2015). Anuario AC/E de cultura digital 2015 [Annual AC/E of digital culture 2015]. Retrieved from https://www.accioncultural.es/es/ebook_anuario_ac_e_cultura_ digital_2015

Area, M. (2008). Innovación pedagógica con TIC y el desarrollo de las competencias informacionales $\mathrm{y}$ digitales [Pedagogic innovation with ICT and the development of information and digital competences]. Investigación en la escuela, 64, 5-18.

Area, M. (2011). Los efectos del modelo 1:1 en el cambio educativo en las escuelas. Evidencias y desafíos para las políticas iberoamericanas [The effects of model 1:1 in educational change in schools. Evidence and challenges for Latin American policies]. Revista Iberoamericana de Educación, 56, 49-74.

Balanskat A., Blamire R., \& Kefala, S. (2006). The ICT impact report. A review of studies of ICT impact on schools in Europe. European Schoolnet. Retrieved from http://insight.eun.org/shared/data/pdf/ impact_study.pdf

Blikstein, P. (2014). Digital fabrication and 'Making' in education: The democratization of invention. In W. Herrmann \& C. Büching (Eds.), FabLabs: Of machines, makers and inventors (pp. 1-21). Bielefeld: Transcript Publishers.

Bosco, A. (2005). Espacio y tiempo: dos elementos clave en la mejora de la escuela [Space and time: Two key elements in the improvement of school]. Kikiriki, 75-76, 36-42.

Bosco Paniagua, A., Larraín Pfingsthorn, V., \& Sancho Gil, J. M. (2008). School +: un proyecto europeo para repensar la enseñanza secundaria [School t: A European project to rethink secondary school teaching]. Revista de Educación, 347, 157-180.

Bosco, A. (2013). Las TIC y la educación escolar: tiempo y espacio como obstáculos o aliados de la mejora [ICT and school education: Time and space as obstacles to or allies of improvement]. Investigación en la escuela, 79, 43-53.

Bosco, A., Sánchez-Valero, J. A., \& Sancho Gil, J. M. (2016) Teaching practice and ICT in Catalonia: Consequences of educational policies. KEDI journal of educational policy, 13(2), 201-220.

Buckingham, D. (2003). Media education: Literacy, learning and contemporary culture. Studies in Art Education, 47(1), 92-96.

Calatayud Salom, M. A. (2018). Hacia una cultura neurodidáctica de la evaluación. La percepción del alumnado universitario [Towards a neurodidactic culture of evaluation. The perception of the university student]. Revista Iberoamericana de Educación, 78 (1) 67-85.

Condie, R., \& Munro, B. (2007). The impact of ICT in schools - a landscape review. BECTA Research. Retrieved from http://webarchive.nationalarchives.gov.uk/20101102103654/publications.becta.org.uk/ download.cfm?resID $=28221$

Couldry, N. (2008). Mediatization or mediation? Alternative understandings of the emergent space of digital storytelling. New Media Society 10(3), 373-391.

Cuban, L. (1993). How teachers taught: Constancy and change in American classrooms, 1890-1990. New 
York, NY: Teachers College Press.

Domingo-Coscollola, M., Onsès-Segarra, J., \& Sancho-Gil, J. M. (2018). La cultura DIY en educación primaria. Aprendizaje transdisciplinar, colaborativo y compartido en DIYLabHub [DIY culture in primary education. Trans-disciplinary, collaborative and shared learning DIYLabHub]. Revista de Investigación Educativa, 36(2), 491-508. doi: http://dx.doi.org/10.6018/rie.36.2.304421 Dougherty, D. (2013). The maker mindset. In M. Honey \& D. E. Kanter (Eds.), Design, make, play: Growing the next generation of STEM innovators. New York, NY: Routledge.

Dussel, I., \& Gutiérrez, D. (2006). Educar la mirada. Políticas y pedagogías de la imagen [Educating the look. Policies and pedagogies of the image]. Buenos Aires, Argentina: Manantial/FLACSO. Elliot, J. (1991). Action research for educational change. Milton Keynes, UK \& Philadelphia, PA: Open University Press.

Flick, U. (2004). Introduction to qualitative inquire. Madrid: Morata.

Orange Foundation. (2016). La transformación digital del sector educación [The digital transformation of the education sector]. Retrieved from http://www.fundacionorange.es/wp-content/ uploads/2016/11/eE_La_transformacion_digital_del_sector_educacion-1.pdf Halverson, E. R., \& Sheridan, K. (2014). The maker movement in education. Harvard Educational Review, 84(4), 495-504. doi: https://doi.org/10.17763/haer.84.4.34j1g68140382063

Hernández, F. (2004). Pasión por el proceso de conocer [Passion for the process of knowing]. Cuadernos de Pedagogía, 332, 46-51.

Hernández, F. (2006). El informe PISA: una oportunidad para replantear el sentido del aprender en la escuela secundaria [The PISA report: An opportunity to rethink the meaning of learning in the secondary school]. Revista de Educación, 1(Special Issue), 357-379.

Hsu, Y. C., Baldwin, S., \& Ching, Y. H. (2017). Learning through making and maker ducation. TechTrends, 61(6), 589-594. doi:https://doi.org/10.1007/s11528-017-0172-6 Intef Report. (2018). Informe Intef (2018) Programación, robótica y pensamiento computacional en el aula. Situación en España, enero de 2018 [Programming, robotics and computational thought in the classroom. Situation in Spain, January 2018]. Retrieved from http://code.intef.es/wp-content/ uploads/2017/o9/Pensamiento-Computacional-Fase-1-Informe-sobre-la-situaci\%C3\%B3n-enEspa\%C3\%B1a.pdf

Latorre, A. (2003). Reaearch-action. Knowing and changing educational practice [La investigaciónacción. Conocer y cambiar la práctica educativa]. Barcelona: Editorial Graó.

Lobato, C., Apodaca, P., Barandiarán, M., \& San José, M. J. (2010). La metodología del aprendizaje cooperativo para la enseñanza de la competencia del trabajo en equipo [The methodology of cooperative learning for teaching teamwork competence]. In Departament de Didàctiques especifiques. Universitat de Girona. II International Didactics Congress (pp. 1-7). Retrieved from http://www2.udg.edu/portals/3/didactiques2010/guiacdii/ACABADES\%2oFINALS/418.pdf. Martin, L. (2015). The promise of the maker movement for education. Journal of Pre-College Engineering Education Research, 5(1-4), 30-39. doi: http://dx.doi.org/10.7771/2157-9288.1099 Meneses, J., Fàbregues, S., Jacovkis, J., \& Rodríguez-Gómez, D. (2014). La introducción de las TIC 
en el sistema educativo español (2000-2010): Un análisis comparado de las políticas autonómicas desde una perspectiva multinivel [The introduction of ICT in Spanish education (2000-2010): A comparative analysis of regional policies from a multi-level approach]. Estudios sobre Educación, 27, $63-90$.

Miño Puigcercós, R., Domingo-Coscollola, M., \& Sancho-Gil, J. (2018). Transforming the teaching and learning culture in higher education from a DIY perspective. Educación XX1, 22(1), 139-16o. doi: http://10.5944/educXX1.20057

Navarro, V. (2018). Metodologías interdisciplinares como herramienta para motivar a alumnado de altas capacidades [Interdisciplinary methodologies as a tool for motivating the student with high capacities]. Revista Iberoamericana de Educación, 78(1), 43-66.

Peppler, K., Halverson, E. R., \& Kafai, Y. (2016). Makeology: Makerspaces as learning Environments (Vol. 1). New York, NY: Routledge.

Romero, M., \& Guitert, M. (2012). Design and use of a collaborative learning environment in the Web 2.o [Diseño y utilización de un entorno de aprendizaje colaborativo basado en la Web 2.o]. RELATEC, 11(1), 83-94.

Sancho, J. M. (2006). De tecnologías de la información y la comunicación a recursos educativos [From information and communication technologies to educational resources]. In J. M. Sancho (Ed.), Tecnologías para transformar la educación (pp. 15-36). Madrid: AKAL/UNIA.

Sancho, J. M., \& Alonso, C. (Eds.) (2012). La fugacidad de las políticas, la inercia de las prácticas. La educación y las tecnologías de la información y la comunicación [The fleetingness of policies, the inertia of practices - Education and information and communication technologies]. Barcelona: Octaedro.

Sigalés, C., Mominó, J. M., \& Meneses, J. (2007). La escuela en la sociedad red: internet en la educación primaria y secundaria [School in the network society: The Internet in primary and secondary education]. Barcelona: Ariel.

Sigalés, C., Mominó, J. M., Meneses, J., \& Badia, A. (2008). La integración de internet en la educación escolar española: situación actual y perspectivas de futuro [The integration of the Internet in the Spanish education system: The current situation and future perspectives]. Barcelona: Open University of Catalunya/Fundación Telefónica.

Stoll, L., Fink, D., \& Earl, L. (2004). About learning and the time it requires. Implications for education. Barcelona: Octaedro.

Tesconi, S. (2015). Crear artefactos para generar conocimiento compartido: el modelo de aprendizaje del movimiento" maker" como herramienta de formación del profesorado [Creating artefacts to generate shared knowledge: The learning model of the "Maker movement" as a teacher-training tool. Communication and technology. New technologies and didactic resources]. Comunicación y Pedagogía, 283, 40-47.

Tesconi, S. (2017) Teacher training in making through the co-design of learning environments.

Universitas Tarraconensis. Revista de Ciències de l'Educació, 2, 6-17.

Tesconi, S. (2018). El docente como maker. La formación del profesorado en making educativo 
[The teacher as maker. Teacher training in educational making] (Unpublished doctoral thesis). Department of Applied Pedagogy, Autonomous University of Barcelona, Spain.

Tesconi, S. \& Arias, L. (2015). The transformative potential of making in teacher education: A case study on teacher training through making and prototyping. In N. Streitz \& P. Markopoulos (Eds.), Proceedings of the third International Conference on Distributed, Ambient, and Pervasive Interactions, Vol. 9189 (pp. 119-128). Retrieved from https://link.springer.com/chapter/10.1007\% 2F978-3-319-20804-6_11 doi: 10.1007/978-3-319-20804-6_11

Tyack, D., \& Tobin, W. (1994). The "grammar" of schooling: Why has it been so hard to change? American Educational Research Journal, 31(3), 453-48o.

Van Maanen, J. (2011). Tales of the field: On writing ethnography. Chicago, IL: University of Chicago Press.

Vossoughi, S., \& Bevan, B. (2015). Making and tinkering. A review of the literature. Retrieved from http://sites.nationalacademies.org/cs/groups/dbassesite/documents/webpage/dbasse_o89888.pdf

\section{Biographical note}

Alejandra Bosco, PhD, is a lecturer of Educational Technology at the Department of Applied Pedagogy at the Autonomous University of Barcelona. She does research in Educational Technology, Teacher Education and Teaching Methods. The main researches that she has developed revolves around the educational potential of digital resources in all educational levels of formal education, but also in non-formal education, and in the daily life. This is the field that corresponds to most her publications.

Noemí SANTIVERI is an associate professor at the Department of Applied Pedagogy at the Autonomous University of Barcelona. Her areas of work and research revolves around the Technologies for Learning and Knowledge applied to the education system.

Susanna Tesconi, PhD, is a lecturer at the Faculty of Computer Science, Multimedia and Telecommunications at Open University of Catalonia in the field of HCI (Human-Computer Interaction). Her research interests include the potential of digital making and creative technology for teacher education, the pedagogy of introductory programming for no STEM students and the relation between creative coding and computational thinking. 